\title{
Operational results of oxyfuel power plant (Callide Oxyfuel Project)
}

\author{
Akihiro KOMAKI*, Takahiro GOTO*, Terutoshi UCHIDA*, Toshihiko YAMADA*, \\ Takashi KIGA* and Chris SPERO** \\ ${ }^{*} \mathrm{HHI}$ Corporation, Business Development department, Energy \& Plant Operations \\ Toyosu IHI Building, 1-1, Toyosu 3-chome, Koto-ku, Tokyo 135-8710, Japan \\ E-mail: akihiro_komaki@ihi.co.jp \\ ${ }^{* *}$ CS Energy, Callide Oxyfuel Services, \\ CS Energy Ltd, Level2, HQ North Tower 540 Wickham Street Fortitude Valley GPO Box 769 Brisbane Qld 4001, Australia
}

\section{Received 1 June 2016}

\begin{abstract}
In 2013, $\mathrm{CO}_{2}$ levels surpassed 400 ppm for the first time in recorded history. So, we are facing global warming due to the increase levels of atmospheric carbon dioxide $\left(\mathrm{CO}_{2}\right)$. As a method of reducing $\mathrm{CO}_{2}$ emissions from the thermal power plants, there are carbon dioxide capture and storage (CCS) technologies. Oxyfuel combustion is one of the $\mathrm{CO}_{2}$ Capture technologies and IHI have developed it since 1989. Then, Callide Oxyfuel Project commenced to apply oxyfiring technology in an existing coal fired power plant and to demonstrate an oxyfuel power plant in March, 2008. Demonstration began in 2012 after existing boiler was retrofitted. During the demonstration for approximately three years, many tests were conducted and many data were collected for commercial use. As a result, we confirmed characteristics of oxyfiring such as total heat absorption, combustion characteristics, emissions of NOx, SOx, carbon-in-ash, operational flexibility from $15 \mathrm{MWe}(50 \% \mathrm{~L})$ to $30 \mathrm{MWe}(100 \% \mathrm{~L})$ and behavior of injected $\mathrm{CO}_{2}$ at the injection site. Total heat absorption of the boiler under oxyfiring was 2 to $3 \mathrm{MW}$ higher because of decreasing heat loss in flue gas and rising temperature of boiler feed water by a flue gas cooler. NO was decomposed in the furnace under oxyfiring because flue gas was recirculated. On the other hand, reaction between $\mathrm{SO}_{2}$ and absorbent such as $\mathrm{Ca}, \mathrm{Mg}$ in ash was not so active regardless of high concentrated $\mathrm{SO}_{2}$ under oxyfiring. Carbon-in-ash was almost $40 \% \sim 70 \%$ in oxyfirng compared with in airfiring because of longer residence time in the furnace. Operational flexibility is important to control oxyfiring operation and it was confirmed that oxyfiring can be operated as well as airfiring. In this paper, operational results are presented in Callide Oxyfuel Project.
\end{abstract}

Key words : Coal, CCS, Oxyfuel, Oxyfiring, $\mathrm{CO}_{2}$, Power plant, Oxy-combustion, Callide, Australia

\section{Introduction}

In 2013, $\mathrm{CO}_{2}$ levels surpassed 400 ppm for the first time in recorded history. Coal fired power plants are considered one of the resources to emit the large amount of $\mathrm{CO}_{2}$. According to "World Energy Outlook 2014" (IEA), coal use in Non-OECD countries will increase up to about three times in 2040 as compared with 1990. Therefore, reducing $\mathrm{CO}_{2}$ concentration in the atmosphere is an important and urgent issue, so the world is focusing on countermeasures. Coal fired power plants still discharge more $\mathrm{CO}_{2}$ emissions during the combustion process than any other fossil fuel power generation plants. Coal is a stable primary energy resource for power generation and will remain as a key energy resource in the future. Therefore, $\mathrm{CO}_{2}$ emissions from coal-fired power plants must be reduced.

Recently, many $\mathrm{CO}_{2}$ capturing processes' which are applied to coal-fired power plants have been developed, such as post-combustion capture and pre-combustion capture. Oxyfuel combustion is also a potential candidate for capturing $\mathrm{CO}_{2}$ from coal-fired power plants. IHI have developed oxyfuel combustion technology since 1989, and a feasibility study on the demonstration project between Australia and Japan started in 2004, followed by the Callide Oxyfuel Project which commenced to demonstrate oxyfuel power plant in 2008. 
During the demonstration, many tests were conducted and many data were collected. Through this project, we confirmed the operational flexibility, improved plant efficiency, $\mathrm{CO}_{2}$ concentration in flue gas, flame stability, and combustion characteristics such as decrease of carbon-in-ash and NO in flue gas etc., under oxyfiring.

In this paper, the operational results of the 30MWe oxyfuel power plant after approximately three years demonstration at the Callide Oxyfuel Project are introduced.

\section{Outline of the oxyfiring system}

In oxyfiring system, $\mathrm{O}_{2}$ is separated from the air by Air Separation Unit (ASU) and supplied to the boiler for coal combustion. Moreover, the flue gas from the boiler is recirculated and mixed with $\mathrm{O}_{2}$ in order to use conventional airfiring technology. Accordingly, the oxyfiring flue gas is emitted mainly comprises of $\mathrm{CO}_{2}$ and $\mathrm{H}_{2} \mathrm{O}$, and will theoretically enhance the $\mathrm{CO}_{2}$ concentration in flue gas up to more than 90 dry\%. The overall CCS concept using an oxyfiring system is shown in Fig.1.

The method for capturing almost pure $\mathrm{CO}_{2}$ involves removing $\mathrm{H}_{2} \mathrm{O}$ and separating non-condensable gases from the oxyfuel gas via a $\mathrm{CO}_{2}$ compression and purification unit (CPU).

The characteristics of oxyfiring technology are as follows :

$>$ Highly-concentrated $\mathrm{CO}_{2}$ can be captured directly from flue gas, because $\mathrm{N}_{2}$ is removed before combustion.

$>$ Efficiency of oxyfuel boiler is far higher than that of an airfiring boiler under the same conditions, because the amount of flue gas is decreased (by approximately one-fifth). The feed-water system can also be integrated with the flue gas system for heat recovery, making it even more efficient.

$>$ NOx emissions are reduced, because recirculation gas is supplied to a furnace and the NOx in the recirculation gas is decomposed. Moreover, NOx can be removed at the CPU.

$>$ Enriched $\mathrm{O}_{2}$ and increasing residence time in the coal combustion process can reduce carbon-in-ash.

$>\quad$ The system can be applied to existing power plants as well as new construction power plants.

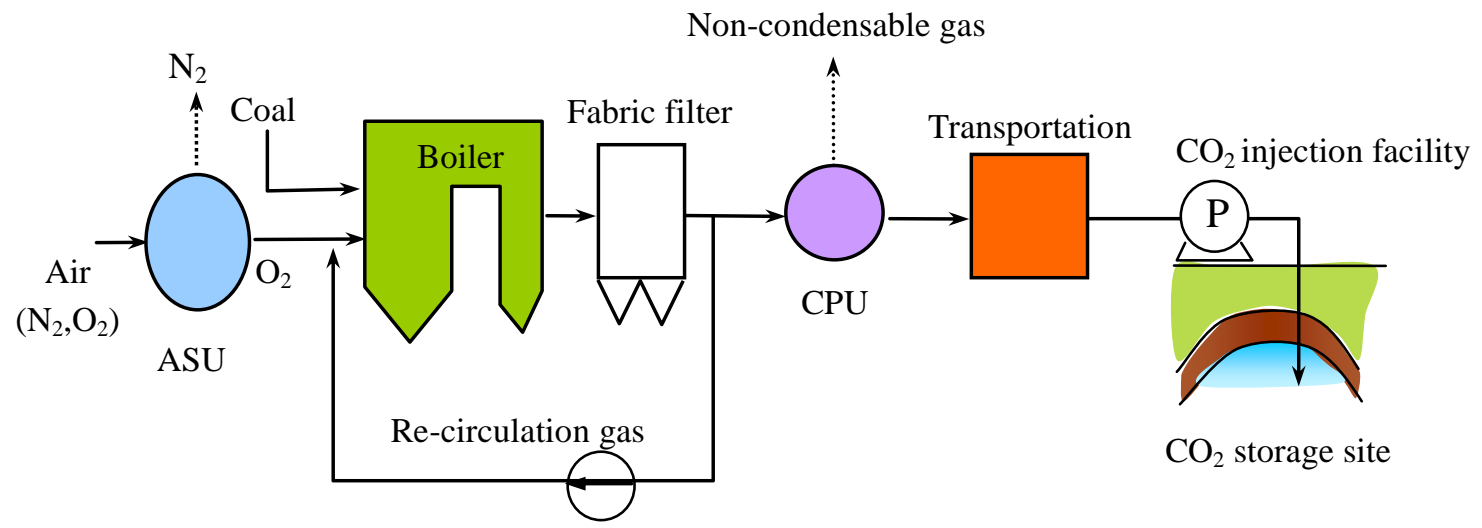

Fig.1 Concept of the oxyfiring system

The oxyfiring system plays a significant role as an optional technology for capturing $\mathrm{CO}_{2}$ from coal-fired power plants. This technology is a focus in many countries and they have conducted research and development to realize the commercial oxyfuel power plants.

\section{Callide Oxyfuel Project}

Callide Oxyfuel Project in central Queensland, Australia, was established in 2008. Callide-A, which was a retrofit of an existing power plant with a capacity of 30MWe, was the largest operating oxyfuel power plant in the world that sold electricity to Australia. This was achieved with funding from the Australian and Japanese governments, the Queensland state Government, and was followed by research results from 1989 in Japan. Before Callide Oxyfuel Project commenced, various evaluations were conducted regarding oxyfiring for realizing demonstration at Callide-A such as combustion characteristics, heat transfer, ignition and safety and so on. These results are shown in the other paper (Yamada et al., 2010). 
The project milestones to date are shown in Table 1. The overview of Callide-A power plant is shown in Fig.2 and the oxyfiring process in Callide-A is shown in Fig.3. The specification of Callide-A boiler was written in the paper (Komaki et al., 2013).

This project was composed of three stages. In stage 1, the existing boiler was retrofitted to an oxyfuel boiler. The ASU and the CPU were installed. In stage 2, the $\mathrm{CO}_{2}$ captured by oxyfiring system was transported by truck and stored underground. In stage 3 , the project outcomes have been summarized including the data which had been acquired through the operation. The objectives of stage 1 involved analyzing the design and cost data so that it could be applied to existing plants, and accumulating operational experience, as well as demonstrating the oxyfuel boiler system and CPU.

The oxyfuel power plant was demonstrated and the various tests were performed from March 2012 to March 2015. The $\mathrm{CO}_{2}$ captured from the oxyfuel power plant was transported and injected into the storage layer.

Table 1 Milestones of the Callide Oxyfuel Project

\begin{tabular}{|c|l|}
\hline Month, Year & \multicolumn{1}{|c|}{ Course } \\
\hline 2004 & Feasibility study of the Callide oxyfuel Project commenced. \\
\hline March, 2006 & MoU (Memorandum of Understanding) signed \\
\hline October, 2006 & Australian Government's Low-emission Technology Demonstration Fund funding announcement \\
\hline March, 2008 & Callide Oxyfuel Project Joint Venture agreements finalized \\
\hline August, 2008 & Refurbishment of Unit A4 at Callide-A Power Station commenced \\
\hline October, 2008 & Official launch of the Callide Oxyfuel Project \\
\hline January, 2009 & Refurbishment of Unit A4 at Callide A Power Station completed \\
\hline October, 2009 & Earthworks commenced at Callide A Power Station \\
\hline January, 2010 & Earthworks completed and foundation excavations commenced at Callide A Power Station \\
\hline March, 2011 & Boiler modification completed for oxyfiring at Callide A Power Station \\
\hline April, 2011 & First coal firing in air mode after boiler oxyfiring modifications \\
\hline March, 2012 & First boiler operation in full oxyfiring mode \\
\hline December, 2012 & Demonstration phase began \\
\hline February, 2015 & Oxyfuel operation of 10,000 hours achieved \\
\hline March, 2015 & Demonstration phase completed \\
\hline
\end{tabular}

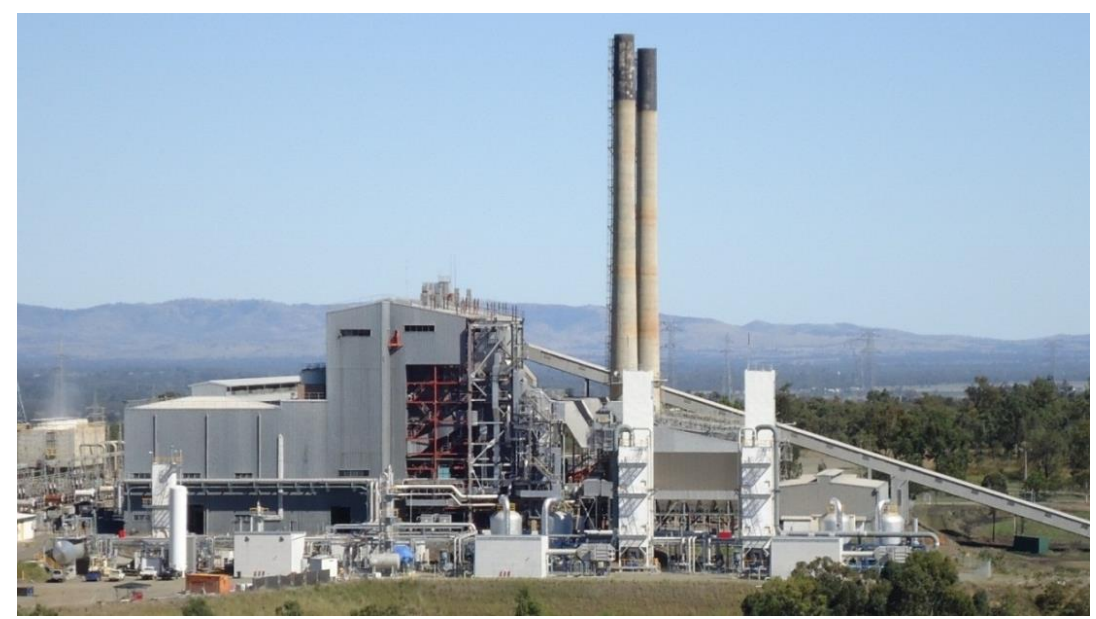

Fig.2 Overview of Callide-A power station 


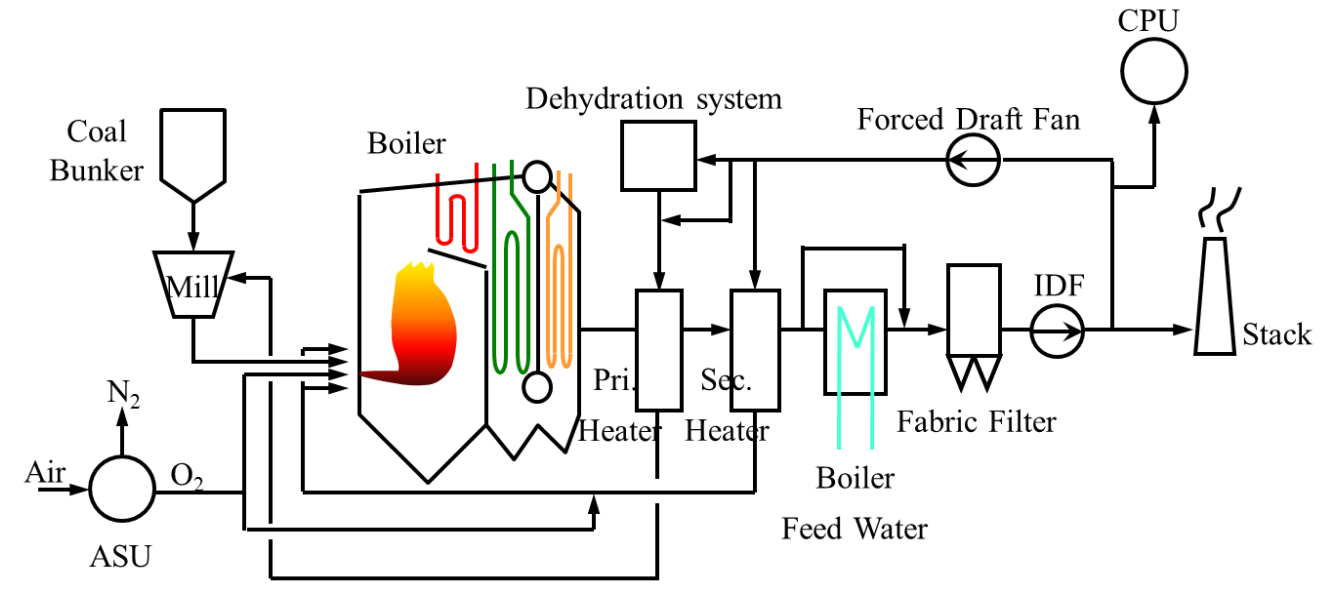

Fig.3 Oxyfiring process in Callide-A

\section{Operational results of the oxyfuel power plant}

The Project team operated the oxyfiring power plant for approximately three years from March 2012 when $\mathrm{O}_{2}$ was supplied to the boiler. Initial operation results are referred to the other paper (Komaki et al., 2013). Then, various basic characteristics of the oxyfuel boiler were confirmed. This section introduces the major results of the oxyfuel boiler in demonstration. Many tests were conducted in order to confirm the characteristics of oxyfuel boiler by using different mill configuration, loads, $\mathrm{O}_{2}$ concentration in total gas (inlet $\mathrm{O}_{2}$ concentration) and so on. The results from the demonstration of the oxyfuel boiler are shown as follows.

$>$ Operational flexibility

$\checkmark \quad$ Combustion in various coal

$\checkmark \quad$ Load ramp up \& down test

$\checkmark$ Turn-down test

$\checkmark$ Optimization of mode transition

$>$ Confirmation of boiler performance

$\checkmark \quad$ 30MWe operation at both airfiring and oxyfiring

$\checkmark \quad$ Various boiler inlet- $\mathrm{O}_{2}$

$\checkmark \quad$ Direct- $\mathrm{O}_{2}$ injection to the flame

$\checkmark \quad$ Bypass operation of dehydration device

$\checkmark \quad$ Simulated staging combustion

$\checkmark \quad$ Exposure test of boiler tubes for high temperature and materials for low temperature

$>$ Reliability

$\checkmark \quad$ Operation hours

$\checkmark \quad$ Inspection of equipment

As a result of demonstration, Callide-A achieved the strong track records as follows.

$\checkmark \quad$ Total generation: 14,800 hours

$\checkmark \quad$ Oxyfuel operation: 10,200 hours

$\checkmark \quad \mathrm{CO}_{2}$ capture operation: 5,600 hours

$\checkmark \quad$ Coal burned: 320,000 tones

\subsection{Total heat absorption of oxyfuel boiler}

The amount of flue gas through the burners is approximately $70 \%$ under oxyfiring compared with airfiring. Heat absorption is defined as heat transferred from radiation and convection. Total heat absorption of the boiler is included furnace, $1 \mathrm{SH}$, evaporator and $2 \mathrm{SH}$. It was 2 to $3 \mathrm{MW}$ higher under oxyfiring, because heat loss of flue gas was decreased and heat of flue gas was recovered in order to raise temperature of boiler feed water by a flue gas cooler. Therefore, plant efficiency under oxyfiring was enhanced. Then, there was no significant difference regarding convection between the bank and the furnace under both airfiring and oxyfiring. These results were almost the same by combustion test facilities and simulation at the stage of feasibility study before the operation (Yamada et al., 2007). 


\subsection{Combustion characteristics}

Figure 4 and 5 show carbon-in-ash and the combustion characteristics about NOx, SOx in both airfiring and oxyfiring respectively. Figure 4 shows the weighted average value of carbon-in-ash of each hopper after burning blended bituminous coal and every ash from 13 hoppers was sampled and analyzed. Regarding "Oxyfiring+direct- $\mathrm{O}_{2}$ " data in Coal B and D was not obtained. In Callide-A, two $\mathrm{O}_{2}$ lances for each burner were what we call direct- $\mathrm{O}_{2}$ installed in order to evaluate the effect of supplying pure $\mathrm{O}_{2}$ near the burners. The maximum capacity was set about $10 \%$ of total $\mathrm{O}_{2}$ which was supplied to the boiler. From the test results of direct- $\mathrm{O}_{2}$ injection test, carbon-in-ash in oxyfiring with direct- $\mathrm{O}_{2}$ was further decreased compared with airfiring and oxyfiring, carbon-in-ash was almost $40 \%$ 70\% in oxyfirng compared with in airfiring because of the longer residence time in the furnace for the small amount of flue gas. In the meantime, in Fig.5, corrective value to $12 \% \mathrm{CO}_{2}$ of $\mathrm{NO}$ and $\mathrm{SO}_{2}$ were used in order to compare on the basis of emissions amount. Conditions of flue gas $\mathrm{O}_{2}$ concentration at the boiler exit during the tests were the same in oxyfiring as in airfiring. The NOcorr, with a $12 \% \mathrm{CO}_{2}$ corrective value, declines around $60 \%$ with oxyfiring because NO was decomposed in recirculated flue gas in the furnace. In fact, it was reported in the research paper (Okazaki and Ando, 1997) that the effect of a reduction of recycled NO in the furnace was dominant and more than $50 \%$ of recycled NO was reduced to become $\mathrm{N}_{2}$ through the chemical reaction in the combustion zone. This means NOcorr emissions can be reduced in the oxyfiring. In oxyfiring, the source of NOx is mainly fuel NOx and thermal NOx by air leakage into the boiler.

On the other hand, $\mathrm{SO}_{2}$ in recirculated flue gas was not so different between airfiring and oxyfiring from the Fig.5.

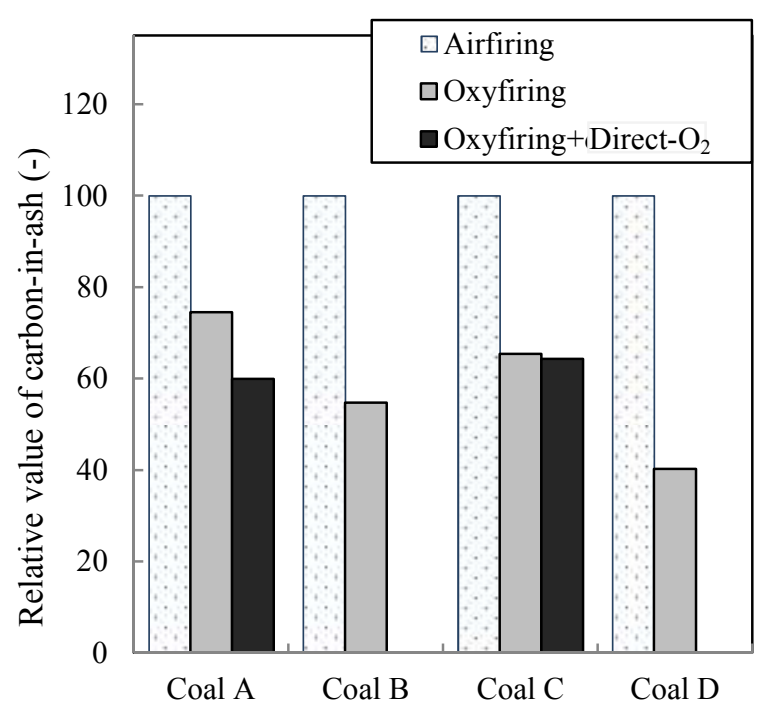

Fig.4 Carbon-in-ash in various coal and conditions This means $\mathrm{SO}_{2}$ under oxyfiring is much more concentrated than under airfiring. Reaction between $\mathrm{SO}_{2}$ and absorbent such as $\mathrm{Ca}, \mathrm{Mg}$ in ash was not so active regardless of high concentrated $\mathrm{SO}_{2}$ under oxyfiring. From this result, DeSOx facility needs to be installed if there is trouble regarding $\mathrm{SO}_{2}$
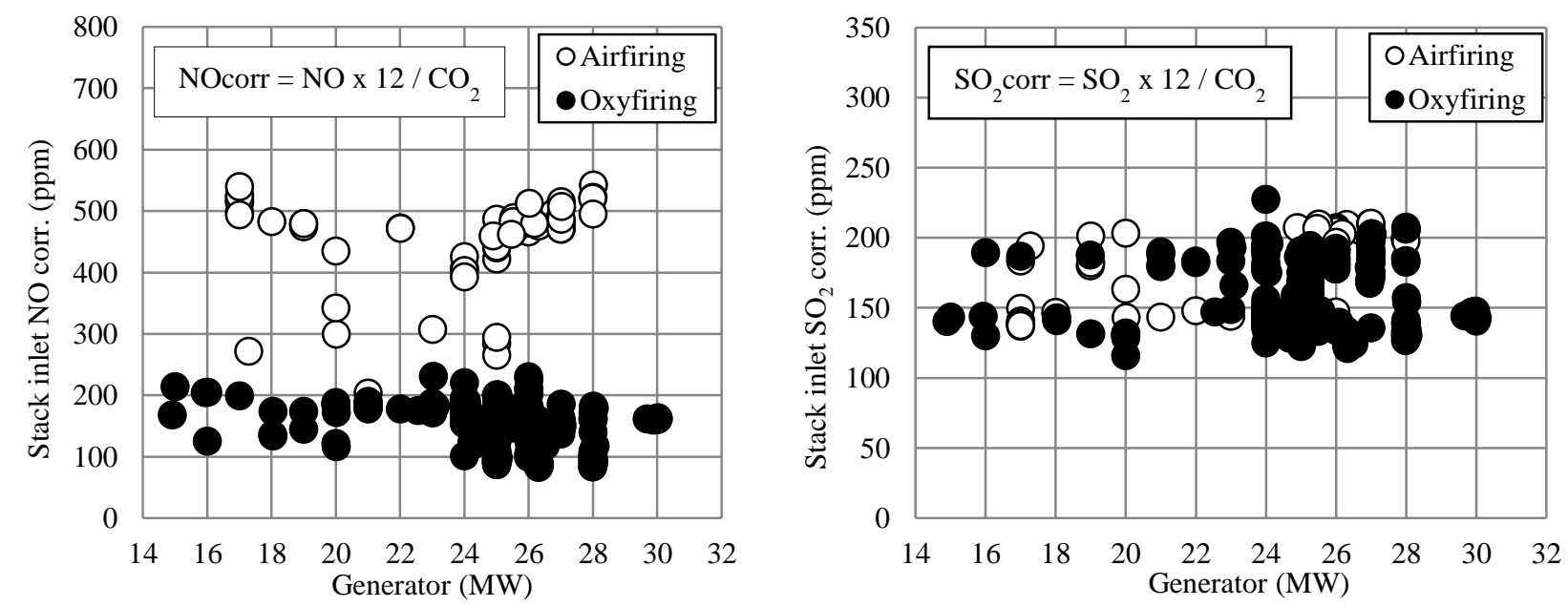

Fig.5 Difference of combustion characteristics between airfiring and oxyfiring 


\subsection{Various boiler inlet $\mathrm{O}_{2}$ tests}

The various boiler inlet $\mathrm{O}_{2}$ operations were conducted to check operational flexibility. It is important that oxyfiring can be operated as well as airfiring at minimum and maximum load. Boiler inlet $\mathrm{O}_{2}$ is defined as $\mathrm{O}_{2}$ concentration in the total amount of boiler inlet flow such as primary flow and secondary flow and so on. Operational range in airfiring and oxyfiring is shown in Fig.6. Through the operation, boiler performance such as steam condition was maintained during the oxyfiring operation as well as the airfiring. However, the boiler outlet gas temperature was decreased in oxyfiring because the heat absorption of the boiler was slightly increased as discussed in section 4.1. It means plant efficiency can be improved by oxyfiring. Then, heat flux on the furnace wall was also increased by increasing inlet- $\mathrm{O}_{2}$ as expected. This result shows that flame temperature rose as boiler inlet $\mathrm{O}_{2}$ concentration was increased, and it caused the energy of radiation to increase.

The photos of flame were taken from the observation windows near the burner throat and brightness of flame was different depending on the boiler inlet $\mathrm{O}_{2}$ as shown in Fig.7. These photos were taken by the same camera and the same setting. Flame location was closer to burner throat due to the reduction of gas volume and higher $\mathrm{O}_{2}$ concentration in combustion gas, when boiler inlet $\mathrm{O}_{2}$ was $30 \%$.

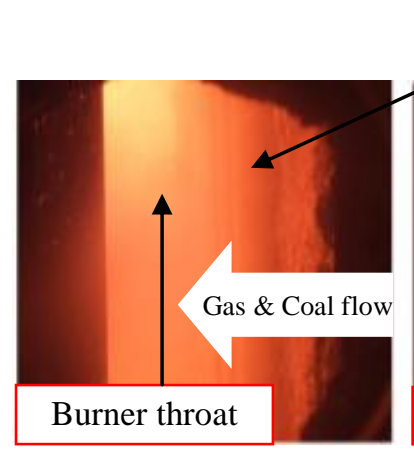

$\underline{24.5 \%}$

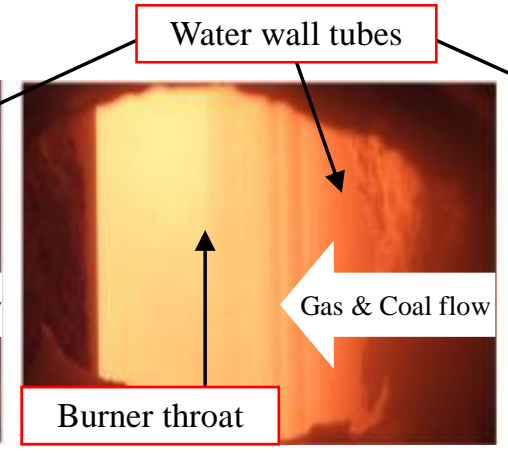

$\underline{27 \%}$

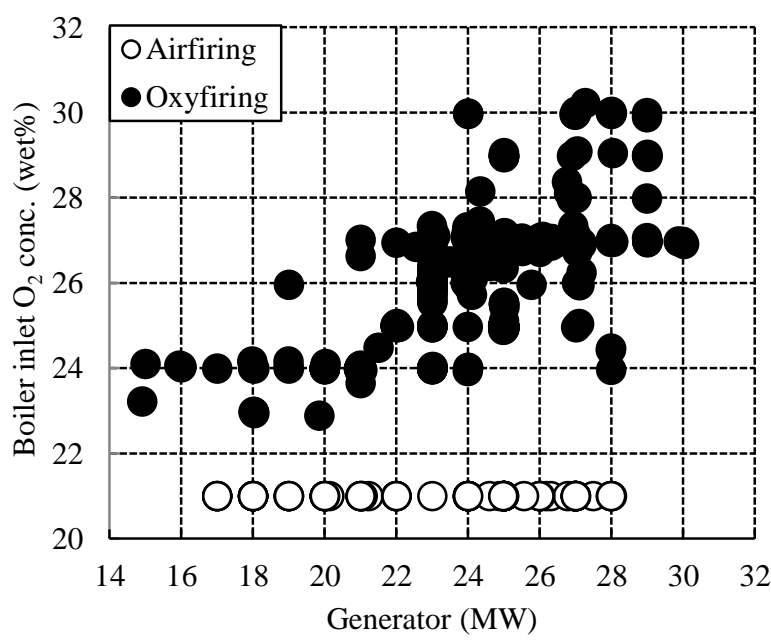

Fig.6 Operational range in airfirng and oxyfirng

Fig.7 Photos of the flame in oxyfiring with various inlet- $\mathrm{O}_{2}, 24.5 \%, 27 \%$ and $30 \%$ at $28 \mathrm{MWe}$

\subsection{Turn-down test in oxyfiring}

At the design stage, the existing burners were reused, 30MWe operation was required in both airfiring and oxyfiring and the minimum load under oxyfiring was set to be $24 \mathrm{MWe}$ with inlet $\mathrm{O}_{2}$ of between 24 and $30 \%$, because flame stability and heat balance of flue gas were concerned. Through the test, the stability of flame was confirmed at 24MWe and there was a possibility to reduce the load. Therefore, turn-down test of the oxyfuel boiler was conducted by the appropriate operational condition monitoring the flame shape and stability in visual and the level of flame detection.

As a result, operational range down to $15 \mathrm{MWe}$ was achieved that was equivalent to airfiring operation as shown in Fig.6. The minimum load was $21 \mathrm{MWe}(70 \% \mathrm{~L})$ when the boiler inlet $\mathrm{O}_{2}$ was controlled at $27 \%$. And also minimum load was $15 \mathrm{MWe}(50 \% \mathrm{~L})$ when the boiler inlet $\mathrm{O}_{2}$ was controlled from 23 to $24 \%$. During turn-down test, burner flames look stable and the boiler operation such as steam condition and flue gas condition were also stable. 


\section{5 $\mathrm{CO}_{2}$ purity at $\mathrm{CPU}$ and $\mathrm{CO}_{2}$ injection}

The $\mathrm{CO}_{2}$ concentration in oxyfuel flue gas at the $\mathrm{CPU}$ inlet is an important factor for the economics of the $\mathrm{CO}_{2}$ capture plant. The target value of $\mathrm{CO}_{2}$ concentration at CPU inlet was 70 dry\% and this was generally achieved under the condition of 28 to 30MWe operation as predicted from calculations based on excess combustion $\mathrm{O}_{2}$ and expected air ingress rates into the boiler. In commercial oxyfuel power plants, it will be very important to strictly minimize the air ingress into the boiler process in order to achieve targeted $\mathrm{CO}_{2}$ concentration in flue gas. From the lessons of the Callide oxyfuel demonstration, a number of measures to reduce the air ingress and to increase the concentration of $\mathrm{CO}_{2}$ in the flue gas to values exceeding 85 dry\% have been identified.

In the $\mathrm{CPU}$, oxyfuel flue gas was purified to obtain almost pure $\mathrm{CO}_{2}$ through the following process equipment: low-pressure wet scrubber with caustic soda, compression, high-pressure wet scrubber, drier, cryogenic separation of $\mathrm{CO}_{2}$ from non-condensable gases such as $\mathrm{O}_{2}, \mathrm{~N}_{2}$ and $\mathrm{Ar}$, and liquefaction. Final product consisted of $\mathrm{CO}_{2}$ with a purity of over $99.9 \%$ which was retained in a storage tank at a condition of -30 degree $\mathrm{C}, 1500 \mathrm{kPa}(\mathrm{A})$. Figure. 8 shows the sampling of liquefied $\mathrm{CO}_{2}$ for analysis.

In late 2014, a series of $\mathrm{CO}_{2}$ injection tests utilizing $\mathrm{CO}_{2}$ product from Callide-A were undertaken in collaboration with the $\mathrm{CO} 2 \mathrm{CRC}$. The purpose of the injection tests were to evaluate the relative geochemical effects of pure $\mathrm{CO}_{2}$ and $\mathrm{CO}_{2}$ with added impurities $\left(\mathrm{NO}_{2}, \mathrm{SO}_{2}\right.$ and $\left.\mathrm{O}_{2}\right)$ on the reservoir rock and formation water within the Paraette Sandstone (at depth of $\sim 1450 \mathrm{~m}$ ) within the Otway geological basin in Victoria. Figure 9 shows the $\mathrm{CO}_{2}$ injection site.

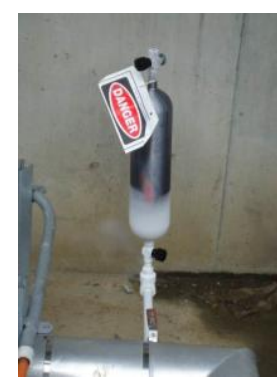

Fig.8 Sampling of liquefied $\mathrm{CO}_{2}$ at Callide-A site

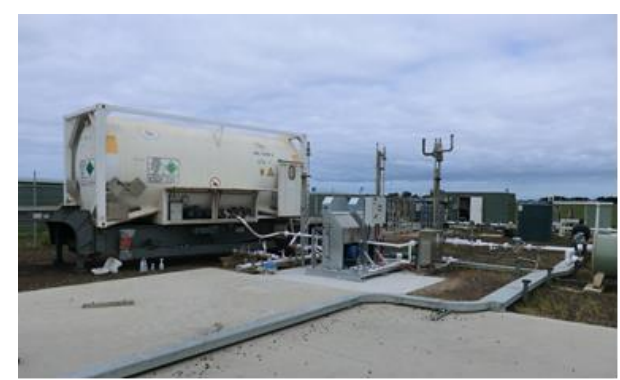

Fig.9 $\mathrm{CO}_{2}$ injection site (CO2CRC Otway)

\section{Business scheme of future oxyfuel power plant}

The feasibility study of 500MWe oxyfuel power plant in Australia was performed. Figure.10 shows the image of future oxyfuel power plant which includes ASU, CPU and flue gas desulfurization (FGD) for commercialization. From the study results, the sales of $\mathrm{N}_{2}$ and $\mathrm{CO}_{2}$ from the oxyfuel power plants are very important and beneficial. Economic efficiency of oxyfuel power plant by selling $\mathrm{CO}_{2}$ and $\mathrm{N}_{2}$ is shown in Fig.11. If $\mathrm{CO}_{2}$ and $\mathrm{N}_{2}$ can be sold effectively, the cost of electricity for oxyfuel power plants can be lower than that for conventional airfiring plants and the oxyfuel power plants will be easy to be applied commercially. Figure 12 shows the proposed project scheme for commercialization.

Oxyfuel combustion for $\mathrm{CO}_{2}$ capture is now ready for scale-up as an outcome of demonstration and learnings of the Callide Oxyfuel Project. In commercial oxyfuel power plants, one of the main problems is the economic efficiency. However, results of the feasibility study, oxyfuel power plant for $\mathrm{CO}_{2}$ capture can be considered to be economically advantageous as compared with other $\mathrm{CO}_{2}$ capture systems.

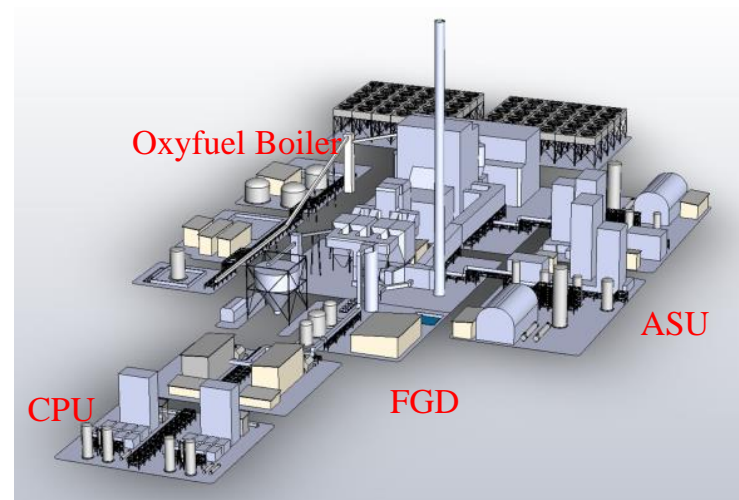

Fig.10 Image of future oxyfuel power plant for commercialization

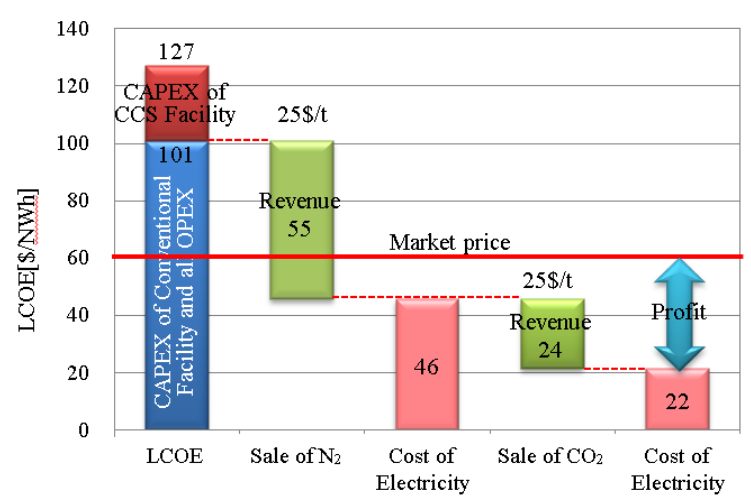

Fig.11 Result of cost study 


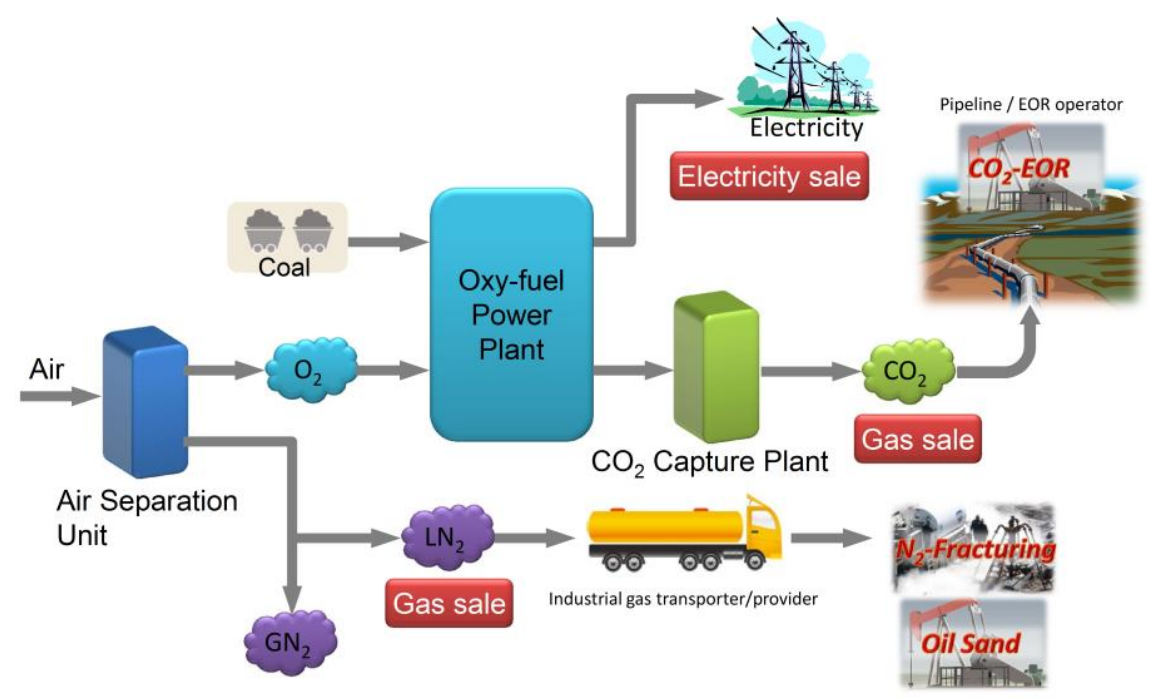

Fig.12 Proposed project scheme

\section{Conclusion}

This report introduced the Callide Oxyfuel Project and operational results of the oxyfuel boiler after demonstration. The data which was accumulated through the many tests will be used towards the commercialization of this technology. To realize this oxyfiring system as a highly-efficient CCS system, we will push forward research and development further. Recently, $\mathrm{CO}_{2}$ emissions ( $\mathrm{kg} / \mathrm{MWh}$ ) from coal fired power plants are restricted less than or equivalent to NGCC (Natural Gas Combined Cycle) level, for example $420 \mathrm{~kg} / \mathrm{MWh}$ in Canada. To comply with regulation, the oxyfuel power plant with CCUS (Carbon Capture, Utilization and Storage) can be expected.

\section{Acknowledgments}

These studies have been greatly supported by the Australian and Japanese Governments, the Queensland State Government, NEDO (New Energy and Industrial Technology Development Organization), as well as by ACALET (Australian Coal Association Low Emission Technology), Glencore, Schlumberger, CO2CRC, J-POWER, Mitsui \& CO., LTD., JCOAL (Japan Coal Energy Center) and many others in Australia and Japan, to which the authors would like to express gratitude for their help and support.

\section{References}

International Energy Agency (IEA), World Energy Outlook 2014 (2014), pp.171-237

Komaki, A., Yamada, T., Kiga, T. and Spero, C., Initial Operation Results of the Oxyfuel Boiler in Demonstration Project, International Conference on Power Engineering (ICOPE-13) (2013), Paper No.203

Okazaki, K. and Ando, T., NOx reduction mechanism in coal combustion with recycled CO2, Energy vol.22, No 2/3 (1997) pp.207-215

Yamada, T., Ishii, T., Takafuji, M. and Iso, Y., Study Results in Demonstration Operation of Oxyfuel Combustion boiler for CO2 Capture, IHI Engineering Review vol.43 No.2 (2010), pp.47 54

Yamada, T., Tamura, M., Fujimori, T., Misawa, N., Kiga, T. and Spero, C., Test Results of Oxy-fuel Combustion and Outline of Demonstration Project in Australia , International Conference on Power Engineering (ICOPE-07) (2007), Paper No.29 